\title{
Neuroprotective effect of carnosine against salsolinol-induced Parkinson's disease
}

\author{
JUN ZHAO $^{1}$, LEI SHI ${ }^{1}$ and LI-RONG ZHANG ${ }^{2}$ \\ ${ }^{1}$ Department of Pharmacy, The Fifth Affiliated Hospital, Zhengzhou University; ${ }^{2}$ Department of \\ Clinical Pharmacology, The Medical College of Zhengzhou University, Zhengzhou, Henan 450052, P.R. China
}

Received May 9, 2016; Accepted March 17, 2017

DOI: $10.3892 /$ etm.2017.4571

\begin{abstract}
Carnosine is a dipeptide of $\beta$-alanine and histidine amino acids. It is widely present in muscle and brain tissues. Carnosine has been demonstrated to be an antioxidant agent that is beneficial in animals. Reactive oxygen species (ROS) and aldehydes are are generated from membrane fatty acid oxidation. The antioxidant potential and toxicity of salsolinol had been extensively studied in vivo and in vitro. The present study analyzed the protective effect of carnosine against Parkinson's disease in the salsolinol-induced rat brain and rat brain endothelial cells. Antioxidant and biochemical markers were determined in vitro and in vivo. Histopathological examination was completed in order to evaluate the protective effect of carnosine on the cellular architecture of salsolinol-induced brain tissue. In order to confirm the protective effect of carnosine further, it was also investigated at an in vitro level using rat brain endothelial cells. Fluorescence and confocal studies indicated reduced apoptosis in the endothelial cells of the rat brain tissue. Antioxidant enzymes and lipid peroxidation levels were renormalized following treatment with carnosine. In addition, carnosine treatment reduced mitochondria-derived ROS in the rat brain endothelial cells. These findings suggest that carnosine may be a therapeutic agent against salsolinol-induced Parkinson's.
\end{abstract}

\section{Introduction}

Carnosine is a dipeptide composed of $\beta$-alanine and histidine amino acids, and is widely abundant in the brain tissues and muscle. It was first identified by a Russian scientist (1) and later in a number of other countries (2-8). Carnosine has been demonstrated to possess antioxidant properties.

Correspondence to: Professor Jun Zhao, Department of Pharmacy, The Fifth Affiliated Hospital, Zhengzhou University, 3 Kangfu Road, Zhengzhou, Henan 450052, P.R. China

E-mail: junzhao1898@hotmail.com

Key words: carnosine, Parkinson's diseases, rats, histopathology, antioxidant enzymes
Reactive oxygen species (ROS) and aldehydes are produced by fatty acid oxidation and it has been indicated that carnosine is able to scavenge these molecules. Carnosine is a zwitterion with a negative and positive end, and is a a well-known compound that reduces advanced glycation end products. End products of advanced glycation may have a critical role in the pathogenesis of a number of diseases, including diabetes mellitus, renal failure, atherosclerosis and neurodegenerative disease (9). Carnosine has also been demonstrated to reduce the development of atherosclerotic plaque (10).

Chronic glycolysis has been reported to accelerate the aging process and the production of carnosine, a crucial therpeutic candidate for neurodegeneration (11). Carnosine is abundant in cerebrospinal fluid, innervated tissues and lenses. Carnosine possesses physiological buffering, wound healing, antioxidant and radioprotectant properties. In addition, it has metal ion chelating, free-radical scavenging, anti-tumour compound, immunomodulator (12) and anti-ageing properties $(13,14)$. However, its proper function remains unknown. The present study investigated the protective effect of carnosine against salsolinol-induced cellular damage.

Free oxygen radicals support the formation of some species that are detrimental to biological molecules. ROS are involved in the aging process (15) and have been indicated to participate in the pathogenesis of joint disease, diabetes, atherosclerosis and Parkinson's disease $(16,17)$. Lipid peroxidation (LPO) generates malondialdehyde (MDA), which may potentially damage the proteins by producing cross-links (18). Previous studies have indicated that carnosine may react with aldehydes to prevent proteins from advanced glycation. This suggests that the high levels of carnosine may be enough to protect against salsolinol induced neurotoxicity.

Salsolinol is a well-known compound that is widely used as a pesticide, piscicide and insecticide. Salsolinol's toxicity has been extensively studied in various in vitro (19-21) and in vivo (22) systems. Synergistic neurotoxicity may also occur when a small dose of different exogenous factors are applied together. Combination of salsolinol and lipopolysaccharide may result in synergistic toxicity (23). A previous study reported that carnosine may be useful against neurotoxicity (9). The present study analyzes the suppressive effect of carnosine against salsolinol-induced Parkinson's disease in rats and rat brain endothelial cells. 


\section{Materials and methods}

Materials. Dulbecco's modified Eagle medium (DMEM), dimethyl sulphoxide (DMSO), sulforhodamine B (SRB), fetal bovine serum (FBS), antibiotics (penicillin-streptomycin) and EDTA were purchased from Sigma-Aldrich (Merck KGaA; Darmstadt, Germany). 2,7-Dichlorodihydrofluorescein diacetate (DCFH-DA) was obtained from Santa Cruz Biotechnology, Inc., (Dallas, TX, USA). Rat brain endothelial cells (bc3h1) were purchased from the American Type Culture Collection (Manassas, VA, USA).

Animals. A total of 24 healthy, male albino rats were purchased from the Shanghai Animal House (Shangai Medical College, Shanghai, China), weighing 180-200 g, and were selected for the present study. Rats were maintained in polypropylene cages, under standard condition (relative humidity $62 \pm 5 \%$ and temperature $25 \pm 0.5^{\circ} \mathrm{C}$ ) with a 12 -h light dark cycle with access to food and water ad libitum. Experimental animal groups were designated as follows: Groups I, II, III and IV (all $\mathrm{n}=4$ ). All animal experiments were carried out in agreement with the ethical standards of China Medical University, which conforms to the Guide for the Care and Use of Laboratory Animals published by the U.S. National Institutes of Health (NIH Publication no. 85-23, revised 1996).

Treatments. Group I received normal saline, group II $100 \mu \mathrm{g}$ salsolinol, group III $50 \mu \mathrm{g}$ salsolinol $+50 \mu \mathrm{g}$ carnosine, and group IV $100 \mu \mathrm{g}$ salsolinol $+100 \mu \mathrm{g}$ carnosine. Following $72 \mathrm{~h}$, the animals were sacrificed, and brain tissues were surgically removed. Brain tissue homogenate was prepared and used for the subsequent investigations.

\section{In vitro studies}

Cell culture. Rat brain endothelial cells were cultured in DMEM growth medium containing FBS and $1 \%$ penicillin-streptomycin. Cells were maintained under standard conditions in a $\mathrm{CO}_{2}$ incubator at $37^{\circ} \mathrm{C}$ with an atmosphere containing $5 \% \mathrm{CO}_{2}$.

Fluorescence microscopy. Rat brain endothelial cells were cultured in a dish. Cells were treated with $100 \mu \mathrm{g} / \mathrm{ml}$ salsolinol, $50 \mu \mathrm{g} / \mathrm{ml}$ salsolinol $+50 \mu \mathrm{g} / \mathrm{ml}$ carnosine or $100 \mu \mathrm{g}$ salsolinol $+100 \mu \mathrm{g}$ carnosine, respectively. Following treatment, cells were centrifuged at $500 \mathrm{xg}$ for $5 \mathrm{~min}$ at $4^{\circ} \mathrm{C}$, and cell volume was adjusted to $10^{4}-10^{5}$ cells $/ \mathrm{ml}$. Cells were incubated with acridine orange $(\mathrm{AO})$ and ethidium bromide $(\mathrm{EB})$ dye for $30 \mathrm{~min}$ at room temperature. Cells were viewed under a fluorescence microscope (Olympus Corp., Tokyo, Japan), as previously described by Muthuraman et al (24).

Determination of ROS production. Rat brain endothelial cells were cultured at $2.5 \times 10^{5}$ cells/well in a 6 -well plate under $37^{\circ} \mathrm{C}$ and $5 \% \mathrm{CO}_{2}$. Cells were treated with $100 \mu \mathrm{g} / \mathrm{ml}$ salsolinol, $50 \mu \mathrm{g} / \mathrm{ml} \mathrm{salsolinol}+50 \mu \mathrm{g} / \mathrm{ml}$ carnosine or $100 \mu \mathrm{g}$ salsolinol $+100 \mu \mathrm{g}$ carnosine, respectively. Following treatment, the cells were treated with DCFH-DA for $30 \mathrm{~min}$ at $37^{\circ} \mathrm{C}$ in an atmosphere containing $5 \% \mathrm{CO}_{2}$. Cells were viewed for fluorescence under a fluorescence microscope (Olympus Corp.), as previously described by Muthuraman et al (24).
Determination of lipid peroxidation. Cells were seeded in a dish at $2.5 \times 10^{5}$ cells/well in a 6 -well plate. Cells were treated with $100 \mu \mathrm{g} / \mathrm{ml}$ salsolinol, $50 \mu \mathrm{g} / \mathrm{ml}$ salsolinol $+50 \mu \mathrm{g} / \mathrm{ml}$ carnosine or $100 \mu \mathrm{g}$ salsolinol $+100 \mu \mathrm{g}$ carnosine, respectively. At the end of all treatment, LPO levels were determined using a kit according to method outlined by Muthuraman et al (25). MDA content was measured with a spectrophotometer at $534 \mathrm{~nm}$ (Cary 100 UV-Vis; Agilent Technologies, Inc., Santa Clara, CA, USA).

Determination of reduced glutathione. Cells were cultured and grown at $2.5 \times 10^{5}$ cells per well in a 6 -well plate. Cells were treated with $100 \mu \mathrm{g} / \mathrm{ml}$ salsolinol, $50 \mu \mathrm{g} / \mathrm{ml}$ salsolinol + $50 \mu \mathrm{g} / \mathrm{ml}$ carnosine or $100 \mu \mathrm{g}$ salsolinol $+100 \mu \mathrm{g}$ carnosine, respectively. GSH levels were measured using a kit according to the method outlined by Muthuraman et al (25). The resultant yellow product was measured at $405 \mathrm{~nm}$ using a Cary 100 $\mathrm{UV}-\mathrm{V}$ is spectrophotometer.

Determination of superoxide dismutase (SOD) and catalase enzyme activities. Cells were seeded in a dish at $2.5 \times 10^{5}$ cells/well in a 6 -well plate. Cells were treated with $100 \mu \mathrm{g} / \mathrm{ml}$ salsolinol, $50 \mu \mathrm{g} / \mathrm{ml}$ salsolinol $+50 \mu \mathrm{g} / \mathrm{ml}$ carnosine or $100 \mu \mathrm{g}$ salsolinol $+100 \mu \mathrm{g}$ carnosine, respectively. SOD and catalase enzyme activities were measured using a kit (SOD assay kit, 19160-1KT-F; catalase assay kit, CAT100-1KT; both Sigma-Aldrich; Merck KGaA) according to the method oulined by Muthuraman et al (25).

\section{In vivo studies}

Determination of lipid peroxidation. Lipid peroxidation was determined using a kit according to the spectrophotometric method of Muthuraman et al (25). MDA content was measured by determining the thiobarbituric acid reactive species (TBARS). The resultant product was determined at $534 \mathrm{~nm}$ using a Cary 100 UV-Vis spectrophotometer.

Determination of reduced glutathione (GSH). The level of GSH was measured using a kit according to the spectrophotometric method of Muthuraman et al (25). The yellow product color was measured using a according to the spectrophotometer at $405 \mathrm{~nm}$.

Determination of SOD and catalase enzyme activities. SOD and catalase enzyme activities were measured using a kit according to the method of Muthuraman et al (25).

Histopathological examination. A total of 24 rats were anesthetized with diethyl ether (Sigma-Aldrich; Merck KGaA) and sacrificed by decapitation. Brain tissues were removed and kept in $4 \%$ paraformaldehyde at $4^{\circ} \mathrm{C}$ for $60 \mathrm{~min}$. Hippocampus sections (4- $\mu \mathrm{m}$ thick) were prepared with use of microtome and stained with hematoxylin and eosin. Sections were qualitatively analyzed by light microscopy as previously described (26).

Statistical analysis. All experimental data are expressed as the mean \pm standard error of the mean. The treated and control groups were compared using Student's t-test. $\mathrm{P}<0.05$ was considered to indicate a statistically significant difference. 

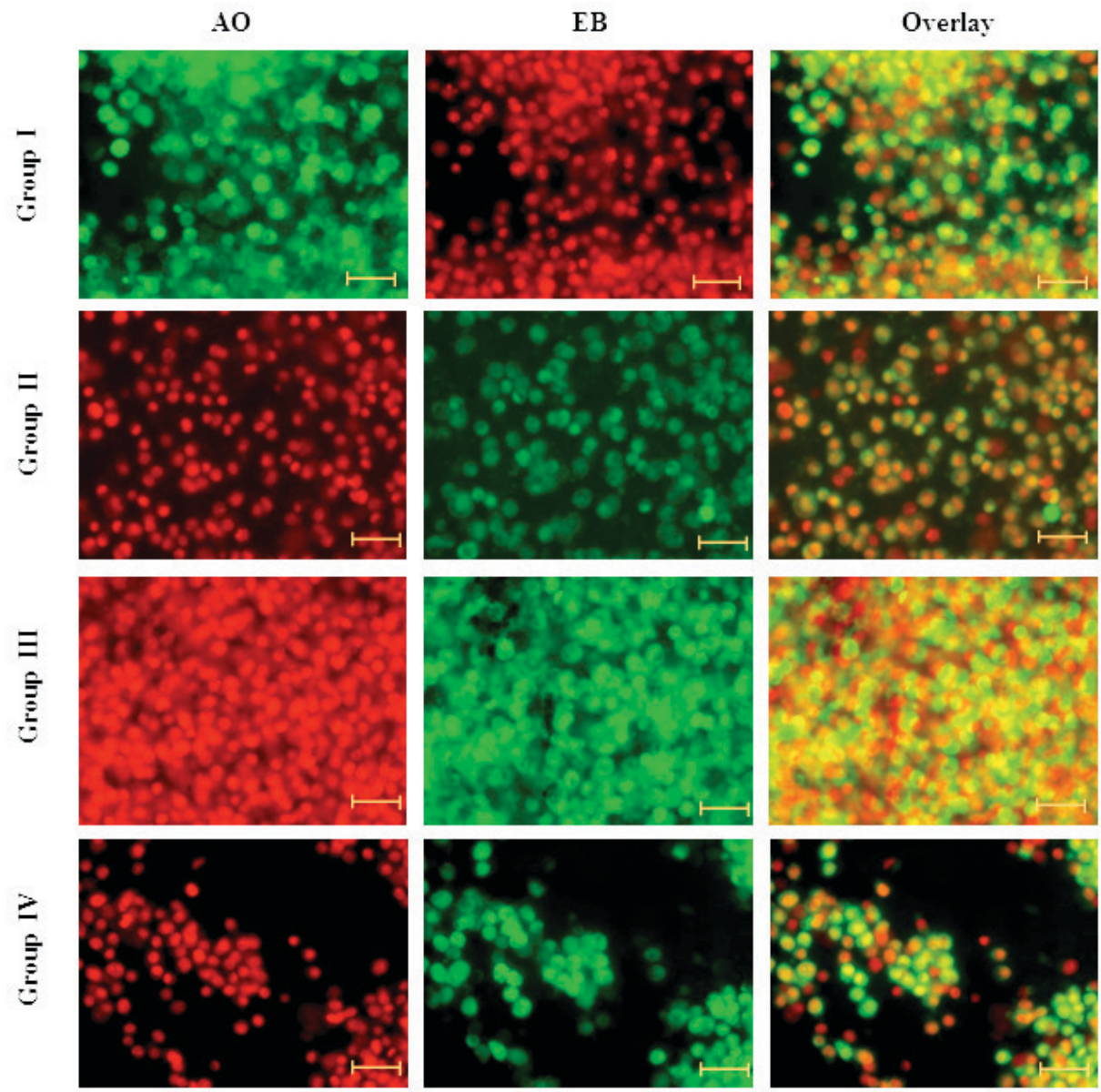

Figure 1. AO/EB double staining by fluorescence microscopy at a magnification of $\mathrm{x} 40$. Cells were seeded in 6 -well plates and cultured for $24 \mathrm{~h}$ to allow adherence, cells were treated as mentioned in the method section. Representative images from three independent experiments. AO, acridine orange; EB, ethidium bromide. Scale bar is $50 \mu \mathrm{m}$.

\section{Results}

Effect of carnosine on apoptosis. Fluorescence microscopy examination was performed to assess whether the neuroprotective effect of carnosine was associated with the morphological aspect of cell death and apoptosis and the morphological features of cell death. DNA-binding AO and EB dyes were used to differentiate between viable and non-viable cells, as chromatin condensation in the stained nucleus is useful to identify viable, apoptotic and necrotic cells. The neuroprotective effect of carnosine against salsolinol in the rat brain endothelial cells was presented (Fig. 1). Fluorescence analysis indicated normal cell size and morphology in control cells (group I); whereas salsolinol-induced rat brain endothelial cells exhibited altered cell morphology, including apoptosis and necrosis (group II). Administration of $50 \mu \mathrm{g} / \mathrm{ml}$ carnosine and $50 \mu \mathrm{g} / \mathrm{ml}$ salsolinol (group III) markedly reduced the apoptosis and necrosis of rat brain endothelial cells. Administration of $100 \mu \mathrm{g} / \mathrm{ml}$ carnosine and $100 \mu \mathrm{g} / \mathrm{ml}$ rotenone (group IV) markedly reduced the occurrence of apoptosis and necrosis in the endothelial cells towards normal levels (Fig. 1).

Effect of carnosine on intracellular ROS level. ROS are able to facilitate signal transduction processes in the cellular region. Fluorescence studies demonstrated that there was little green fluorescence in the control cells (group I), whereas green fluorescence was markedly increased in salsolinol-treated cells (group II). Administration of $50 \mu \mathrm{g} / \mathrm{ml}$ carnosine and $50 \mu \mathrm{g} / \mathrm{ml}$ salsolinol (group III) markedly reduced the level of ROS in rat brain endothelial cells. Administration of $100 \mu \mathrm{g} / \mathrm{ml}$ carnosine and $100 \mu \mathrm{g} / \mathrm{ml}$ salsolinol (group IV) markedly reduced the level of ROS in the rat brain endothelial cells, towards normal levels (Fig. 2).

Effect of carnosine on MDA and GSH content in rat brain endothelial cells. The neuroprotective effect of carnosine against salsolinol-induced toxicity in rat brain endothelial cells is presented in Table I. MDA content in control cells was $21.15 \pm 1.20 \mathrm{nmol} / \mathrm{g}$, whereas it significantly increased to $36.15 \pm 1.0 \mathrm{nmol} / \mathrm{g}$ in salsolinol-treated rat brain endothelial cells (group II; $\mathrm{P}<0.05$; Table I). Administration of $50 \mu \mathrm{g} / \mathrm{ml}$ carnosine and $50 \mu \mathrm{g} / \mathrm{ml}$ salsolinol (group III) significantly reduced $(31.36 \pm 1.2 \mathrm{nmol} / \mathrm{g}) \mathrm{MDA}$ content in the rat brain endothelial cells, compared with group II ( $\mathrm{P}<0.05$; Table I). Administration of $100 \mu \mathrm{g} / \mathrm{ml}$ carnosine and $100 \mu \mathrm{g} / \mathrm{ml}$ salsolinol (group IV) significantly reduced MDA content $(23.7 \pm 1.1 \mathrm{nmol} / \mathrm{g})$ in the rat brain endothelial cells, compared with group II $(\mathrm{P}<0.05$; Table I).

GSH content in control cells was $73.23 \pm 2.2 \mathrm{mg} / \mathrm{g}$ (group I), whereas it was significantly reduced to $34.14 \pm 1.2 \mathrm{mg} / \mathrm{g}$ in 

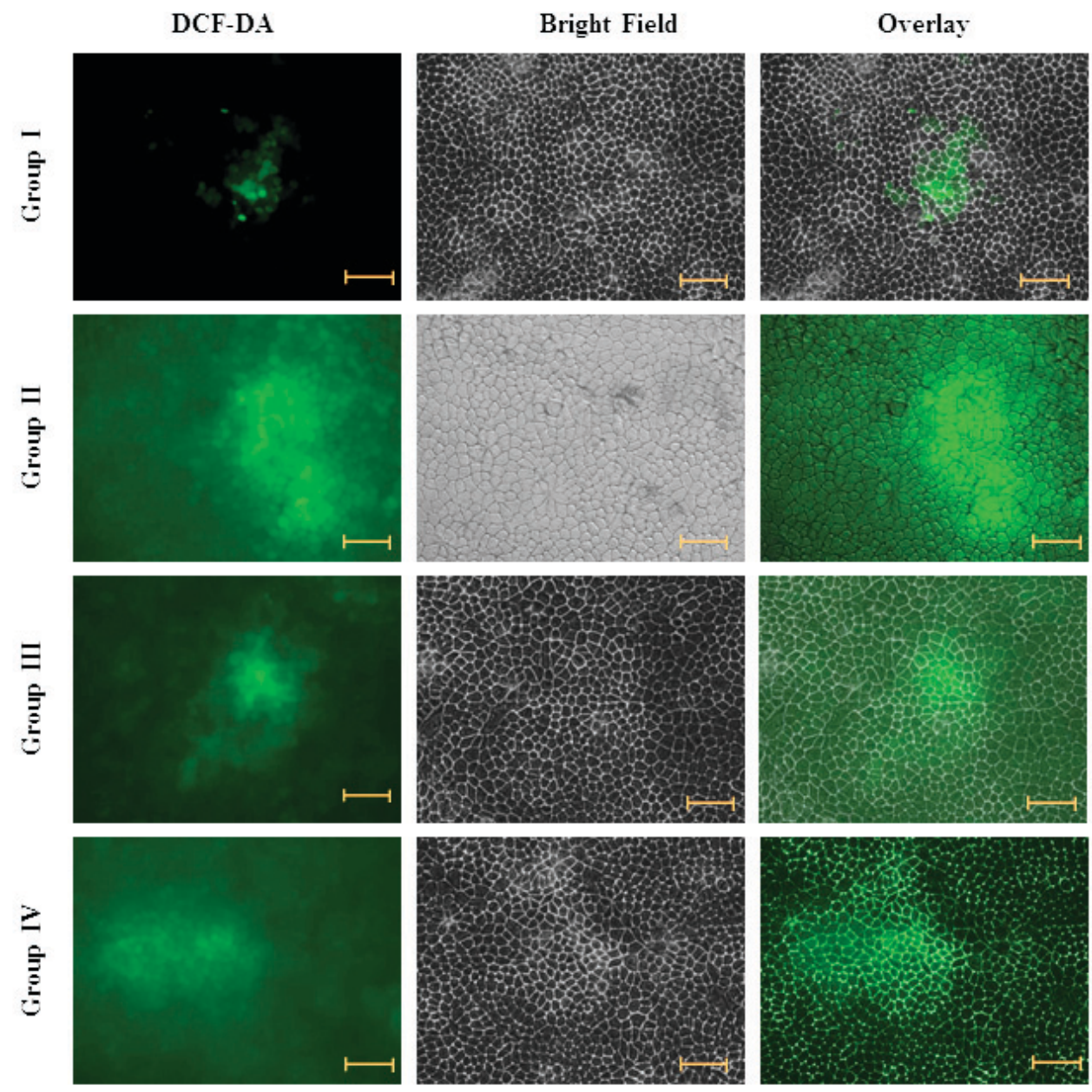

Figure 2. Suppressive effect of carnosine on ROS production. Cells were grown in 6-well plates and allowed to adhere for $24 \mathrm{~h}$. Cells were treated with the carnosine as mentioned in the method. At the end of treatments, cells were stained with 2,7-dichlorodihydro fluorescein diacetate and images were obtained using fluorescence microscopy. Representative images from three independent experiments. ROS, reactive oxygen species. Magnification, x40. Scale bar $=50 \mu \mathrm{m}$.

salsolinol-treated rat brain endothelial cells (group II; $\mathrm{P}<0.05$; Table I). Administration of $50 \mu \mathrm{g} / \mathrm{ml}$ carnosine and $50 \mu \mathrm{g} / \mathrm{ml}$ salsolinol (group III) significantly increased GSH content to $47.45 \pm 1.2 \mathrm{~m} / \mathrm{g}$ in the rat brain endothelial cells, compared with group II $(\mathrm{P}<0.05$; Table I). Administration of $100 \mu \mathrm{g} / \mathrm{ml}$ carnosine and $100 \mu \mathrm{g} / \mathrm{ml}$ salsolinol (group IV) significantly increased GSH content to $64.8 \pm 2.2 \mathrm{mg} / \mathrm{g}$ in the rat brain endothelial cells, compared with group II $(\mathrm{P}<0.05$; Table I).

Effect of carnosine on antioxidant enzymes in rat brain endothelial cells. The neuroprotective effect of carnosine against the salsolinol-induced toxicity of rat brain endothelial cells is presented in Table I. SOD activity was identified to be $2.8 \pm 0.03 \mathrm{U} / \mathrm{mg}$ in the control rat brain endothelial cells (group I), whereas it was significantly reduced to $1.8 \pm 0.02 \mathrm{U} / \mathrm{g}$ in the salsolinol-induced rat brain endothelial cells (group II; $\mathrm{P}<0.05$; Table I). Administration of $50 \mu \mathrm{g} / \mathrm{ml}$ carnosine and $50 \mu \mathrm{g} / \mathrm{ml}$ salsolinol (group III) significantly increased SOD activity to $1.92 \pm 0.02 \mathrm{U} / \mathrm{g}$ in the rat brain endothelial cells, as compared with group II $(\mathrm{P}<0.05$; Table I). Administration of $100 \mu \mathrm{g} / \mathrm{ml}$ carnosine and $100 \mu \mathrm{g} / \mathrm{ml}$ alsolinol (group IV) has significantly increased SOD activity to $2.5 \pm 0.03 \mathrm{U} / \mathrm{g}$ compared with group II $(\mathrm{P}<0.05$; Table I).
Catalase activity was identified to be $6.7 \pm 0.07 \mathrm{U} / \mathrm{g}$ in the control rat brain endothelial cells (group I), whereas it was significantly reduced to $3.33 \pm 0.05 \mathrm{U} / \mathrm{g}$ in the salsolinol-induced rat brain endothelial cells (group II; $\mathrm{P}<0.05$; Table I). Administration of $50 \mu \mathrm{g} / \mathrm{ml}$ carnosine and $50 \mu \mathrm{g} / \mathrm{ml}$ salsolinol (group III) significantly increased catalase activity to $3.8 \pm 0.02 \mathrm{U} / \mathrm{g}$ in the rat brain endothelial cells, as compared with group II $(\mathrm{P}<0.05$; Table I). Administration of $100 \mu \mathrm{g} / \mathrm{ml}$ carnosine with $100 \mu \mathrm{g} / \mathrm{ml}$ salsolinol (group IV) significantly increased catalase activity to $5.75 \pm 0.05 \mathrm{U} / \mathrm{g}$ compared with group II ( $\mathrm{P}<0.05$; Table I).

Effect of carnosine on MDA content in rat brain tissue. The neuroprotective effect of carnosine against salsolinol in male albino rats is demonstrated in Fig. 1. MDA content in the control was $26.40 \pm 1.1 \mathrm{nmol} / \mathrm{g}$, whereas it significantly increased to $59.55 \pm 2.1 \mathrm{nmol} / \mathrm{g}$ in salsolinol treated rat brain (group II; P<0.05). Administration of $50 \mu \mathrm{g} / \mathrm{ml}$ carnosine and $50 \mu \mathrm{g} / \mathrm{ml}$ salsolinol (group III) significantly reduced compared with group II $(48.76 \pm 1.6 \mathrm{nmol} / \mathrm{g}) \mathrm{MDA}$ content in the rat brain $(\mathrm{P}<0.05$. Administration of $100 \mu \mathrm{g} / \mathrm{ml}$ carnosine and $100 \mu \mathrm{g} / \mathrm{ml}$ salsolinol (group IV) significantly reduced MDA content $(34.11 \pm 1.1 \mathrm{nmol} / \mathrm{g})$ in the rat brain $(\mathrm{P}<0.05$; Fig. 3$)$. 
Table I. Effect of carnosine against salsolinol induced LPO, GSH, SOD and catalase levels in the rat brain endothelial cells.

\begin{tabular}{lcccc}
\hline Parameter & Group I & Group II & Group III & Group IV \\
\hline MDA, nmol/g & $21.15 \pm 1.12$ & $36.15 \pm 1.0^{\mathrm{a}}$ & $31.36 \pm 1.2^{\mathrm{b}}$ & $23.70 \pm 1.1^{\mathrm{b}}$ \\
$\mathrm{GSH}, \mathrm{mg} / \mathrm{g}$ & $73.23 \pm 2.2$ & $34.14 \pm 1.2^{\mathrm{a}}$ & $47.45 \pm 1.2^{\mathrm{b}}$ & $64.80 \pm 2.2^{\mathrm{b}}$ \\
$\mathrm{SOD}, \mathrm{U} / \mathrm{mg}$ & $2.80 \pm 0.03$ & $1.80 \pm 0.02^{\mathrm{a}}$ & $1.92 \pm 0.02^{\mathrm{b}}$ & $2.50 \pm 0.03^{\mathrm{b}}$ \\
Catalase, U/g & $6.70 \pm 0.07$ & $3.33 \pm 0.05^{\mathrm{a}}$ & $3.80 \pm 0.02^{\mathrm{b}}$ & $5.75 \pm 0.05^{\mathrm{b}}$
\end{tabular}

${ }^{\mathrm{a}} \mathrm{P}<0.05$ vs. group I (control); ${ }^{\mathrm{b}} \mathrm{P}<0.05$ vs. group II $(\mathrm{n}=6)$. Data are expressed as the mean \pm standard error of the mean. LPO, lipid peroxidation; GSH, glutathione; SOD, superoxide dismutase.

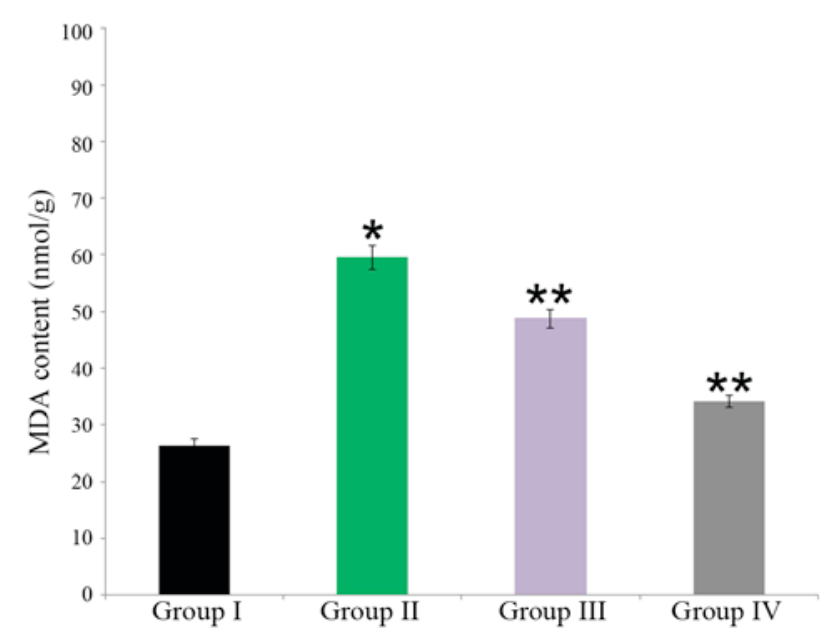

Figure 3. Suppressive effect of carnosine on lipid peroxidation in the male albino rat brain at $48 \mathrm{~h}$. Results are presented as nmol/g compared with the control. ${ }^{*} \mathrm{P}<0.05$ vs. group I (control); ${ }^{* *} \mathrm{P}<0.05$ vs. group II. Data are expressed as mean \pm standard deviation. MDA, malondialdehyde.

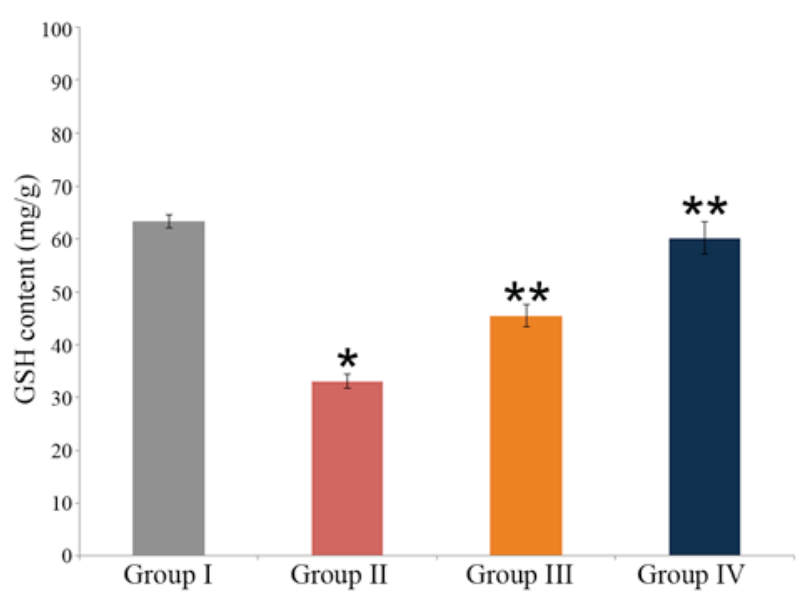

Figure 4. Protective effect of carnosine on GSH content in the male albino rat brain at $48 \mathrm{~h}$. Results are presented as $\mathrm{mg} / \mathrm{g}$ compared with the control. ${ }^{*} \mathrm{P}<0.05$ vs. group I (control); ${ }^{* *} \mathrm{P}<0.05$ vs. group II. Data are expressed as mean \pm standard error of the mean. GSH, glutathione.

Effect of carnosine on GSH content in rat brain tissue. The neuroprotective effect of carnosine against salsolinol in male albino rats is indicated in Fig. 4. The GSH content in the control was $63.3 \pm 1.2 \mathrm{mg} / \mathrm{g}$ (group I), whereas it was significantly reduced to $33.10 \pm 1.2 \mathrm{mg} / \mathrm{g}$ in salsolinol treated rat brain (group II; P<0.05). Administration of $50 \mu \mathrm{g} / \mathrm{ml}$ carnosine and $50 \mu \mathrm{g} / \mathrm{ml}$ salsolinol (group III) significantly increased GSH content to $45.45 \pm 2.1 \mathrm{~m} / \mathrm{g}$ in the rat brain, as compared with the content in group II. Administration of $100 \mu \mathrm{g} / \mathrm{ml}$ carnosine and $100 \mu \mathrm{g} / \mathrm{ml}$ salsolinol (group IV) significantly increased GSH content to $60.21 \pm 3.0 \mathrm{mg} / \mathrm{g}$ in the rat brain, as compared with group II ( $\mathrm{P}<0.05$; Fig. 4).

Effect of carnosine on SOD activity in rat brain tissue. The neuroprotective effect of carnosine against salsolinol in male albino rats is presented in Fig. 5. SOD activity was identified to be $2.53 \pm 0.11 \mathrm{U} / \mathrm{mg}$ in the control rat brain (group I), whereas it was significantly reduced to $1.35 \pm 0.01 \mathrm{U} / \mathrm{mg}$ in the salsolinol treated rat brain (group II; $\mathrm{P}<0.05$ ). Administration of $50 \mu \mathrm{g} / \mathrm{ml}$ carnosine and $50 \mu \mathrm{g} / \mathrm{ml}$ salsolinol (group III) significantly increased SOD activity to $2.01 \pm 0.04 \mathrm{U} / \mathrm{mg}$ in the rat brain compared with group II $(\mathrm{P}<0.05)$. Administration of $100 \mu \mathrm{g} / \mathrm{ml}$ carnosine and $100 \mu \mathrm{g} / \mathrm{ml}$ salsolinol (group IV) significantly increased SOD activity to $2.47 \pm 0.12 \mathrm{U} / \mathrm{mg}$ in the rat brain, as compared with group II ( $\mathrm{P}<0.05$; Fig. 5).

Effect of carnosine on catalase activity in rat brain tissue. The neuroprotective effect of carnosine against salsolinol in male albino rats is presented in Fig. 6. Catalase activity was identified to be $10.14 \pm 0.1 \mathrm{U} / \mathrm{g}$ in the control rat brain (group I), this was significantly reduced to $5.45 \pm 0.13 \mathrm{U} / \mathrm{g}$ in the salsolinol treated rat brain $(\mathrm{P}<0.05$; group II). Administration of $50 \mu \mathrm{g} / \mathrm{ml}$ carnosine and $50 \mu \mathrm{g} / \mathrm{ml}$ salsolinol (group III) significantly increased catalase activity to $6.4 \pm 0.11 \mathrm{U} / \mathrm{g}$ in the rat brain, as compared with group II $(\mathrm{P}<0.05)$. Administration of $100 \mu \mathrm{g} / \mathrm{ml}$ carnosine and $100 \mu \mathrm{g} / \mathrm{ml}$ salsolinol (group IV) significantly increased catalase activity to $8.5 \pm 0.21 \mathrm{U} / \mathrm{g}$ in the rat brain, as compared with group II $(\mathrm{P}<0.05$; Fig. 6).

Effect of carnosine on rat brain histopathology. The neuroprotective effect of carnosine against salsolinol in male albino rats is presented in Fig. 7. Histopathological analysis demonstrated a normal cellular architecture in control rats (group I), whereas salsolinol-induced rat brain exhibited altered cellular structure, including apoptosis and necrosis of cells (group II). Administration of $50 \mu \mathrm{g} / \mathrm{ml}$ carnosine and $50 \mu \mathrm{g} / \mathrm{ml}$ salsolinol (group III) markedly improved the rat brain cells. Administration of $100 \mu \mathrm{g} / \mathrm{ml}$ carnosine and $100 \mu \mathrm{g} / \mathrm{ml}$ salsolinol (group IV) markedly improved the rat brain cell architecture, returning to normal (Fig. 7). 


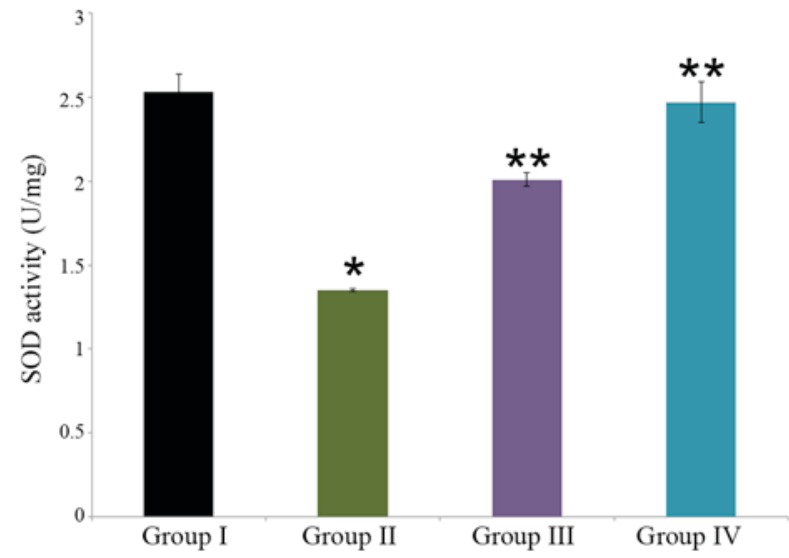

Figure 5. Protective effect of carnosine on SOD activity in the male albino rat brain at $48 \mathrm{~h}$. Results are presented as U/g compared with the control. ${ }^{*} \mathrm{P}<0.05$ vs. group I (control); ${ }^{* *} \mathrm{P}<0.05$ vs. group II. Data are expressed as mean \pm standard error of the mean.

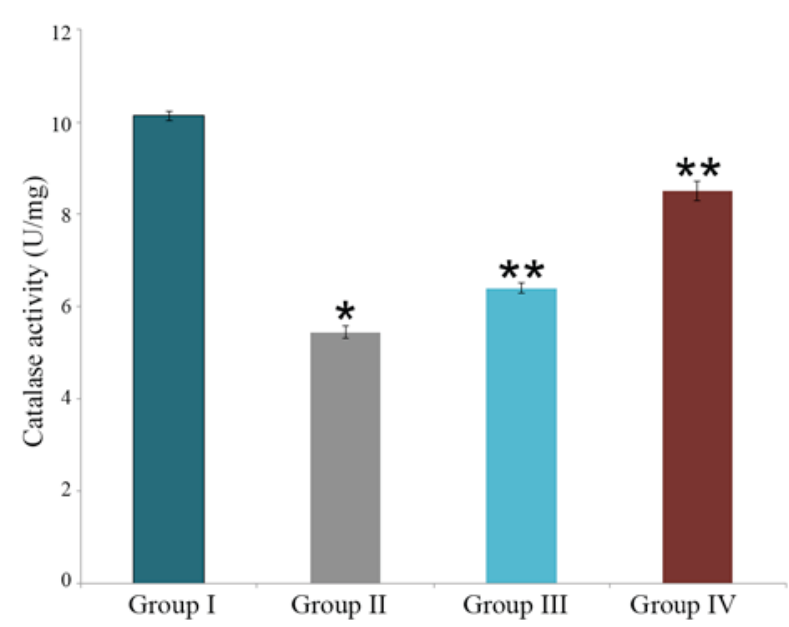

Figure 6. Protective effect of carnosine on catalase activity in the male albino rat brain at $48 \mathrm{~h}$. Results are presented as U/g compared with the control. ${ }^{*} \mathrm{P}<0.05$ vs. group I (control); ${ }^{* *} \mathrm{P}<0.05$ vs. group II. Data are expressed as the mean \pm standard error of the mean. SOD, superoxide dismutase.

\section{Discussion}

The experimental results in the present study demonstrated that carnosine had neuroprotective effects on the male albino rats, rat brain endothelial cells and appear to exhibit a clear dose-dependence when exposing cells to higher concentrations. Induction of tumor cell apoptosis is an essential property of anti-cancer therapeutics (27). Apoptosis is defined as a morphological and biochemical alteration of cells and therefore, a morphological study is vital for apoptosis investigations. In the current study, carnosine treatment exerted increasing suppressive effects on the male albino rats and rat brain endothelial cells with increasing concentrations.

Morphological studies are important to understand the cytotoxic impact of the carnosine with apoptosis. Carnosine has been demonstrated to protect rat brain endothelial cells against the toxic effects of amyloid peptides. Carnosine protects cells by scavenging MDA and 4-hydroxynonenal, which usual react with macromolecules (28). Therefore, ROS production and involvement are one of the potential mechanisms. Interference
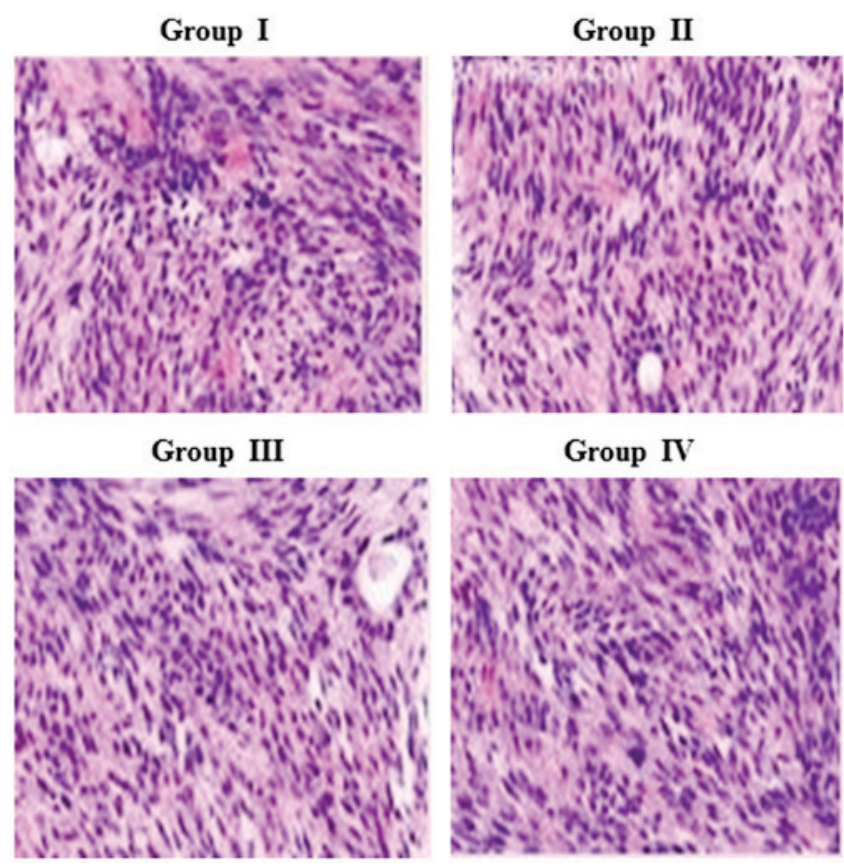

Figure 7. Protective effect of carnosine on the cellular architecture of the male albino rat brain at $48 \mathrm{~h}$. Hippocampus sections were prepared $(5-\mu \mathrm{m}$ thick) and stained with hematoxylin and eosin. Stained sections were analyzed qualitatively by light microscope at a magnification of $x 40$. Scale bar is $50 \mu \mathrm{m}$.

using stimulating peptide catabolism, scavenging superoxide radicals and effects on second messenger processes are considered to be further explanations. The results of the current study indicate that carnosine treatment reduced lipid peroxidation in the rat brain and endothelial cells. Carnosine also significantly increased GSH and antioxidant enzyme activities, which further confirms the protective effects of carnosine.

Carnosine significantly normalized cell morphology at an in vivo and in vitro level. It has been demonstrated that accumulation of glycated and damaged proteins occurs during normal aging (29) and in larger quantities during Alzheimer's disease $(30,31)$. Carnosine protects against age-related macromolecular damage via the production of ROS (1). Carnosine is an anti-glycating compound (13) and previous studies have indicated that carnosine may delay senescence (14) and inhibit DNA oxidation in human fibroblasts (32). The present study demonstrated that carnosine acts against lipid peroxidation and antioxidant markers by altering its toxicity and inhibiting protein damage. Brain, muscle and lens tissues in animals contain high amount of carnosine (33).

The results of the current study indicated that salsolinol may induce neurotoxicity in the male albino rat brain and rat brain endothelial cells $(34,35)$. Treatment with carnosine exhibited a significant improvement in neurotoxicity. The lower concentration $(50 \mu \mathrm{g} / \mathrm{ml})$ of carnosine used in the present study was able to significantly protect against neurotoxicity induced by salsolinol in the rat brain and endothelial cells. Salsolinol is known to cause neurotoxicity via the inhibition of mitochondrial complex II and by initiating apoptosis through the increased production of free radicals (36). Carnosine has been demonstrated to possess neuroprotective effects through the inhibition of apoptosis with a consequent reduction in the 
production of ROS. Although, even at a high concentration, carnosine may partially recover or inhibit the toxicity induced by salsolinol in the rat brain and endothelial cells. Investigation of carnosine in combination with other drugs for their synergistic action would be worthwhile and notable as it may be helpful in determining the therapeutic effect of the carnosine as a monotherapy and in combination with other drugs.

In conclusion, salsolinol exerted neurotoxicity in the male albino rat brain tissues and rat brain endothelial cells. This cytotoxicity was reversed following treatment with carnosine, as demonstrated by the results of the current study. The in vivo levels of MDA, GSH, SOD and catalase were renormalized following carnosine treatment, and the cellular architecture of the rat brain also began to return to normal. Morphological and apoptotic changes were evaluated by fluorescence microscopy, which confirmed that there was a reduction of apoptosis following carnosine treatment. The level of ROS was reduced in the current study due to a decrease in the oxidative stress. MDA, GSH, SOD and catalase levels were also measured in vitro, and these findings matched the in vivo measurements. The experimental results of the present study may conclude that salsolinol exerts neurotoxicity, and treatment with carnosine may significantly reverse this toxicity.

\section{References}

1. Gulewitsch Wl and Amiradžibi S: Ueber das carnosin, eine neue organische base des Fleischextractes. Berichte Der Deutschen Chemischen Gesellschaft 33: 1902-1903, 1900.

2. Aruoma OI, Laughton MJ and Halliwell B: Carnosine, homocarnosine and anserine: Could they act as antioxidants in vivo? Biochem J 264: 863-869, 1989.

3. Choi SY, Kwon HY, Kwon OB and Kang JH: Hydrogen peroxide-mediated $\mathrm{Cu}, \mathrm{Zn}$-superoxide dismutase fragmentation: Protection by carnosine, homocarnosine and anserine. Biochim Biophys Acta 1472: 651-657, 1999.

4. Klebanov GI, Teselkin YuO, Babenkova IV, Lyubitsky OB, Rebrova OYu, Boldyrev AA and Vladimirov YuA: Effect of carnosine and its components on free-radical reactions. Membr Cell Biol 12: 89-99, 1998

5. Babizhayev MA, Seguin MC, Gueyne J, Evstigneeva RP, Ageyeva EA and Zheltukhina GA: L-carnosine (beta-alanyl-Lhistidine) and carcinine (beta-alanylhistamine) act as natural antioxidants with hydroxyl-radical-scavenging and lipid-peroxidase activities. Biochem J 304: 509-516, 1994.

6. Karton A, O'Reilly RJ, Pattison DI, Davies MJ and Radom L: Computational design of effective, bioinspired $\mathrm{HOCl}$ antioxidants: The role of intramolecular $\mathrm{Cl}+$ and $\mathrm{H}+$ shifts. J Am Chem Soc 134: 19240-19245, 2012.

7. Chan KM and Decker EA: Endogenous skeletal muscle antioxidants. Crit Rev Food Sci Nutr 34: 403-426, 1994.

8. Kohen R, Yamamoto Y, Cundy KC and Ames BN: Antioxidant activity of carnosine, homocarnosine, and anserine present in muscle and brain. Proc Natl Acad Sci USA 85: 3175-3179, 1988.

9. Vistoli G, De Maddis D, Cipak A, Zarkovic N, Carini M and Aldini G: Advanced glycoxidation and lipoxidation end products (AGEs and ALEs): An overview of their mechanisms of formation. Free Radic Res 47 (Suppl 1): S3-S27, 2013.

10. Reddy VP, Garrett MR, Perry G and Smith MA: Carnosine: A versatile antioxidant and antiglycating agent. Sci Aging Knowledge Environ 2005: pe12, 2005.

11. Hipkiss AR: Does chronic glycolysis accelerate aging? could this explain how dietary restriction works? Ann N Y Acad Sci 1067: 361-368, 2006

12. Boldyrev AA, Formazyuls VE and Sergienko VI: Biological significance of histidine-containing dipeptides with special reference to carnosine: Chemistry, distribution, metabolism and medical application. Sov Sci Rev D Physicochem Biol 13: 1-60, 1994.

13. Hipkiss AR, Holliday R, McFarland G and Michaelis J: Carnosine and senescence. Lifespan 4: 1-3, 1993.
14. McFarland GA and Holliday R: Retardation of the senescence of cultured human fibroblasts by carnosine. Exp Cell Res 212: 167-175, 1994.

15. Harman D: Aging: A Theory Based on Free Radical and Radiation Chemistry. UCRL Publication no. 3078. Univesrity of California, Berkrley, CA, 1955.

16. Halliwell B and Gutteridge JMC: Free Radicals in Biology and Medicine. Clarendon Press, Oxford, 1989.

17. Schubert D, Behl C, Lesley R, Brack A, Dargusch R, Sagara Y and Kimua H: Amyloid peptides are toxic via a common oxidative mechanism. Proc Natl Acad Sci USA 92: 1989-1993, 1995.

18. Libondi T, Ragone R, Vincenli D, Stiuso P, Auricchio G and Collona G: In vitro cross-linking of calf lens alpha-crystallin by malondialdehyde. Int J Peptide Protein Res 44: 342-347, 1994.

19. Hartley A, Stone JM, Heron C, Cooper JM and Schapira AH: Complex I inhibitors induce dose-dependent apoptosis in PC12 cells: Relevance to Parkinson's disease. J Neurochem 63: 1987-1990, 1994

20. Gao HM, Hong JS, Zhang W and Liu B: Distinct role for microglia in rotenone-induced degeneration of dopaminergic neurons. J Neurosci 22: 782-790, 2002.

21. Freestone PS, Chung KK, Guatteo E, Mercuri NB, Nicholson LF and Lipski J: Acute action of rotenone on nigral dopaminergic neurons-involvement of reactive oxygen species and disruption of Ca2+ homeostasis. Eur J Neurosci 30: 1849-1859, 2009.

22. Caboni P, Sherer TB, Zhang N, Taylor G, Na HM, Greenamyre JT and Casida JE: Rotenone, deguelin, their metabolites, and the rat model of Parkinson's disease. Chem Res Toxicol 17: 1540-1548, 2004.

23. Gao HM, Hong JS, Zhang W and Liu B: Synergistic dopaminergic neurotoxicity of the pesticide rotenone and inflammogen lipopolysaccharide: Relevance to the etiology of Parkinson's disease. J Neurosci 23: 1228-1236, 2003.

24. Muthuraman P, Kim DH, Muthuviveganandavel V, Vikramathithan J and Ravikumar S: Differential bio-potential of ZnS nanoparticles to normal MDCK cells and cervical carcinoma HeLa cells. J Nanoscience Nanotechnol 16: 8279-8286, 2016.

25. Muthuraman P, Muthuviveganandavel V and Kim DH: Cytotoxicity of zinc oxide nanoparticles on antioxidant enzyme activities and mRNA expression in the cocultured $\mathrm{C} 2 \mathrm{C} 12$ and $3 \mathrm{~T} 3-\mathrm{L} 1$ cells. Appl Biochem Biotechnol 175: 1270-1280, 2015.

26. Muthuviveganandavel V, Muthuraman P, Muthu S and Srikumar K: A study of low dose cypermethrin induced histopathology, lipid peroxidation and marker enzyme changes in male rats. Pesticide Biochemistry Physiol 91: 12-16, 2008

27. Frankfurt OS and Krishan A: Apoptosis-based drug screening and detection of selective toxicity to cancer cells. Anticancer Drugs 14: 555-561, 2003.

28. Markesbery WR: Oxidative stress hypothesis in Alzheimer's disease. Free Radical Biol Med 23: 134-147, 1997.

29. Stadtman ER: Protein oxidation and aging. Science 257: 1220-1224, 1992.

30. Smith MA, Perry G, Richey PL, Sayre LM, Anderson VE, Beal MF and Kowall N: Oxidative damage in Alzheimer's. Nature 382: 120-121, 1996.

31. Smith MA, Rudnicka-Nawrot M, Richey PL, Praprotnik D, Mulvihill P, Miller CA, Sayre LM and Perry G: Carbonyl-related post-translational modification of neurofilament protein in neurofibrillary pathology in Alzheimer's disease. J Neurochem 64: 2660-2666, 1995.

32. Kantha SS, Wada S, Tanaka H, Takeuchi M, Watabe S and Ochi H: Carnosine sustains the retention of cell morphology in continuous fibroblast culture subjected to nutritional insult. Biochem Biophys Res Commun 223: 278-282, 1996.

33. Perry TL, Hansen S, Stedman D and Love D: Homocarnosine in human cerebrospinal fluid: An age-dependent phenomenon. J Neurochem 15: 1203-1206, 1968.

34. Das JR and Tizabi Y: Additive protective effects of donepezil and nicotine against salsolinol-induced cytotoxicity in SH-SY5Y cells. Neurotox Res 16: 194-204, 2009.

35. Song JX, Shaw PC, Wong NS, Sze CW, Yao XS, Tang CW, Tong Y and Zhang YB: Chrysotoxine, a novel bibenzyl compound selectively antagonizes $\mathrm{MPP}^{+}$, but not rotenone, neurotoxicity in dopaminergic SH-SY5Y cells. Neurosci Lett 521: 76-81, 2012.

36. Storch A, Kaftan A, Burkhardt K and Schwarz J: 1-Methyl-6,7-dihydroxy-1,2,3,4-tetrahydroisoquinoline (salsolinol) is toxic to dopaminergic neuroblastoma SH-SY5Y cells via impairment of cellular energy metabolism. Brain Res 855: 67-75, 2000 